\title{
KONTRIBUSI PERMAINAN HITAM HIJAU TERHADAP KETERAMPILAN LARI SPRIN MURID SMP NEGARI 11 KOTA JAMBI
}

\author{
Ilham $^{1}$, Arsil $^{2}$, Muhammad $\mathrm{Ali}^{3}$ \\ ${ }^{12}$ Fakultas Ilmu Keolahragaan Universitas Jambi \\ bugis.ilham@yahoo.co.id \\ arsil@gmail.com \\ ali_fik@yahoo.co.id
}

\begin{abstract}
Generally this research is for knowing the contribution of hitam hijau and sentuh batu games on the ability to sprints for female student of SMPN 11 jambi, specificially this research is for knowing: (1) the contribution of hitam hijau games on the ability to sprints. (2) the contribution of sentuh batu games on the ability to sprints. (3) differences in the contribution of hitam hijau and sentuh batu games on the ability to sprint. And the advantage of this research are (1) for the physical education teacher is as the information form of the game that can be used as a learning media in order to achieve the indicator skills to run sprints . (2) For the trainers, is for building the ability to sprint for athlete can be done with the hitam hijau and sentuh batu games. The research method that used in this research is the experimental method, using the two groups pretest post test design. The variable in this research is the ability to sprint as the binding variable and the hitam hijau and sentuh batu games as the free variable. The data that we collected were analyzed with the t test, but before that we conducted the normality and homogenity test. The hypothesis testing result are (1) $t$ hitung $(9,35)>t$ table $(1,69)$. (2) $t$ hitung $(6,44)>t$ table $(1,69)$. (3) $t$ hitung $(4,54)>t$ tabel $(2,24)$. Thus it can be concluded that (1) hitam hijau games gives the significant contribution for the ability to sprint. (2) sentuh batu games gives the significant contribution for the ability to sprint. (3) there are significant differences in the contribution of hitam hijau and sentuh batu games for the ability to sprint. Hitam hijau game is far better than sentuh batu games.
\end{abstract}

Keywords : Hitam hijau, Sentuh batu, The ability to sprint

\section{PENDAHULUAN}

Pendidikan yang diselenggarakan harus disesuaikan dengan amanat yang tercantum dalam Undang-undang Republik Indonesia Nomor 20 tahun 2003 tentang Sistim Pendidikan Nasional, BAB II Pasal 3 menyatakan bahwa Pendidikan nasional berfungsi mengembangkan kemampuan dan membentuk watak serta peradaban bangsa yang bermartabat dalam rangka mencerdaskan kehidupan bangsa bertujuan untuk berkembangnya potensi peserta didik agar menjadi manusia yang beriman dan bertakwa kepada Tuhan Yang Maha Esa.

Karena itu mulai dari kurikulum, penyelenggaraan pendidikan serta tenaga pendidiknya harus dirancang dan dipersiapkan dengan baik sesuai dengan karekteristik bangsa kita agar peserta didik dapat mengikuti proses pendidikan dan menerima pelajaran dengan baik sesuai sesuai dengan indicator pembelajaran tersebut.
Pengajaran atletik khususnya lari sprint sangat membosankan bagi anak anak SMP, karena itu guru penjas sangat diharapkan mampu mecari jenis permainan untuk membentuk keterampilan berlari bagi anakanak muridnya, dengan ini juga tercapai kebugaran jasmani pesertadidiknya, hal ini sesuai apa yang dikemukakan (Dini Rosdiani, 2012:34), bahwa Pendidikan jasmani yang diselenggarakan di sekolah pada dasarnya memiliki tujuan untuk meningkatkan kebugaran jasmani, pencapaian keterampilan peserta didik dalam berolahraga dan meningkatkan taraf kesehatan.

Teknik berlari dapat dilatih dengan memperkenalkan keterampilan-keterampilan yang berkaitan dengan unsur dari semua kegiatan perlombaan dalam lari sprint, karena tidak adanya cara untuk melatih semua gerakan sekaligus, maka diterapkan latihan yang bervariasi dan latihan difokuskan pada aspek-aspek khusus, (Dikdik Zafar Sidik, 2011:4). 
Merujuk ungkapan di atas, menunjukkan bahwa guru dalam mengajar atau pelatih dalam melatih suatu keterampilan dituntut untuk mencari permainan-permainan yang berkaitan dengan unsur-unsur yang ingin dicapai dalam pembelajaran atau latihan, karena keterampilan merupakan kemampuan belajar motorik yang menekankan pada kualitas gerak anak seperti kecepatan, kelincahan, koordinasi, power dan keseimbangan, maka belajar keterampilan gerak untuk membentuk keterampilan lari sprint dapat dilakukan dengan menggunakan permainan hitam hijau dan sentuh batu.

Pembelajaran Atletik, khususnya lari sprint, bila diamati kurang diminati oleh murid-murid SMP, karena tidak dalam bentuk permainan, agar murid-murid dapat menyenagi maka pembelajaran atletik khususnya lari sprint sebaiknya buat dalam bentuk permainan, sehingga murid-murid dapat memiliki keterampilan lari sprint, dan mereka lebih senang mengikuti pembelajaran tersebut, untuk itu maka perlu dicoba dengan melakukan pendekatan permainan hitam hijau dan sentuh batu sehingga indikator pembelajaran yaitu memiliki keterampilan lari sprint dapat tercapai, murud-murid juga menjadi senang mengikuti pembelajaran karena sambil belajar mereka bermainan indicator pembelajaran juga dapat tercapai. Hal ini sesuai yang dikemukakan (H.Y.S. Santosa Giriwijoyo dan Didik Zafar Sidik, 2012:87), bahwa Anak menyukai berbagai cabang olahraga permainan. Keinginan anak untuk menyerap sebanyak mungkin pengetahuan dan keterampilan merupakan bagian dari pertumbuhan dan perkembangan anak yang bersifat alami. Pengetahuan dan keterampilan itu menjadi bekal untuk digunakan pada berbagai situasi yang tepat,

Barkaitan dengan hal di atas, maka sangat tepat bila guru penjas menggunakan pendekatan bermain dalam pembelajaran penjas orkes, karena hanya di sekolah-sekolah kemungkinan untuk melakukan permainan setelah pulang sekolah kemungkinannya sangat kecil. Kendalanya adalah tidak tersedianya area atau lapangan terutama di kota-kota besar untuk memainkan permainan tersebut dan telah didominasinya permainan multi media seperti Play Station, Nintendo, acara televise dan lain sebagainya.

Pelaksanaan permainan hitam hijau dan sentuh batu membutuhkan kecepatan berlari, kelincahan, kekuatan, kelentukan, kecepatan reaksi, karena itu peneliti berasumsih bahwa permainan tersebut dapat digunakan sebagai media pembelajaran untuk membentukan keterampilan lari sprint. Berdasarkan asumsi tersebut maka peneliti ingin mengetahui apakah permainan hitam hijaudan sentuh batu dapat membentuk keterampilan lari sprint pada Murid SMP Negeri 11 Kota Jambi.

Agar permasalahan dalam penelitian ini tidak meluas dalam pembahasannya, dan dengan maksud untuk memperjelas dan mempertajam arah dan fokus penelitian ini maka permasalahannya perlu dibatasi yaitu Keterampilan lari sprint sebagai variabel terikat, sementara variabel bebas meliputi permainan hitam hijau dan sentuh batu. Keterampilan lari sprint meliputi star jongkok, teknik berlari dan teknik melewati garis finis.

Berdasarkan uraian di atas maka permasalahan dalam penelitian ini yaitu: 1) Apakah terdapat kontribusi permainan hitam hijau terhadap keterampilan lari sprin murid SMP Negari 11 Kota Jambi. 2) Apakah terdapat kontribusi permainan sentuh batu terhadap keterampilan lari sprin murid SMP Negari 11 Kota Jambi dan 3) Apakah terdapat perbedaan kontribusi antara permainan hitam hijau dengan sentuh batu terhadap keterampilan lari sprint Murid SMP Negeri 11 Kota Jambi.

KAJIAN LETERATUR DAN PENGEMBANGAN HIPOTESIS

\section{A. Belajar Lari Sprint}

Belajar merupakan kegiatan mental yang tidak dapat disaksikan dari luar, apa yang sedang terjadi dalam diri seseorang yang sedang belajar tidak dapat diketahui secara lansung dengan proses pengamatan terhadap orang itu. Demikian pula dengan hasilnya, bahwa hasil belajar seseorang itu tidak nampak sebelum orang tersebut melakukan sesuatu yang menampakkan perubahan, pengetahuan (kognitif), sikap, (afektif) dan keterampilan (psikomotor) dalam bentuk tingkah laku dari situlah dapat diketahui bahwa orang tersebut telah berhasil dalam belajarnya.

$$
\text { Ricard A Schmidt, (1988:123) }
$$

menyatakan bahwa belajar merupakan perubahan yang relatif permanen sebagai akibat latihan dan pengalaman. Karena itu guru harus dapat memberikan pemahaman yang benar pada anak muridnya, karena apa yang disampaikan diharapkan diterima oleh anak 
muridnya dan melekat pada diri anak murid tersebut. Robert N Singer (1992:56), juga mengemukakan bahwa belajar adalah perubahan-perubahan atau perubahan tingkah laku yang potensial akibat latihan dari pengalaman masa lalu terhadap tugas tertentu. Cherly A Coker (2004:3) mengemukakan belajar adalah perubahan yang relatif tetap (permanen) pada kemapuan setiap individu untuk melaksanakan sebagai hasil dari suatu pengalaman atau praktik.

Lari sprint atau lari jarak pendek merupakan suatu cara berlari siswa atau atlit harus menempu seluruh jarak dengan kecepatan yang semaksimal mungkin, (Aib Syarifuddin, 1992/1993:62). Dalam pelaksanaan pembelajaran lari sprint pelaksanaannya dimulai dari belajar star jongkok, kegiatan berlari atau teknik berlari dan diakhiri dengan melewati garis finis. Adapun jarak tempuh dari lari jarak sprint adalah: $100 \mathrm{~m}, 200 \mathrm{~m}, 400 \mathrm{~m}$. Selain itu ada juga lari sambung atau estafet dengan jarak $4 \mathrm{x}$ $100 \mathrm{~m}$ dan $4 \times 400 \mathrm{~m}$, selain itu ada juga yang dinakan lari gawang dengan jarak tempuh untuk putri yaitu 100 , dan $400 \mathrm{~m}$, untuk putra jarak tempuh adalah $110 \mathrm{~m}$ dan $400 \mathrm{~m}$.

Dari pendapat di atas dapat disimpulkan bahwa belajar adalah segala aktivitas mental yang berlangsung dalam interaksi secara aktif dengan lingkungan yang menghasilkan perubahan-perubahan dalam pengetahuan, sikap, pemahaman dan keterampilan, dimana perubahan itu bersifat relatif konstan dan berbekas. Dalam kaitannya dengan lari sprint berarti siswa atau atlit dapat menempuh jarak yang telah ditentukan.

\section{B. Keterampilan Lari Sprint}

Keterampilan adalah kemampuan seseorang untuk menggunakan akal, fikiran, ide dan kreatifitasnya dalam mengerjakan, mengubah, menyelesaikan ataupun membuat sesuatu menjadi lebih bermakna sehingga menghasilkan sebuah nilai dari hasil pekerjaan tersebut, dalam keterampilansikaladi.blogspot.com 2013/07/defenisi-atau-pengertian-

keterampilan.html (diakses tanggal 4 juni 2015). Keterampilan/ kemampuan tersebut pada dasarnya akan lebih baik bila terus diasah dan dilatih untuk menaikkan kemampuan sehingga akan menjadi ahli atau menguasai dari salah satu bidang keterampilan yang ada.

Keterampilan psikomotor hanya dapat dicapai dengan latihan atau belajar. Hasil belajar atau latihan dalam suatu keterampilan dapat memberikan pengaruh positif terhadap keterampilan lain. Hal ini dapat diistilakan dengan transfer latihan, transfer latihan terjadi apabila kebiasaan yang telah terbentuk sebelumnya memberikan pengaruh terhadap penguasan penampilan atau relearning dari kebiasaan berikutnya, (Rusli Lutan, 1988: 324). Sebagai contoh anak-anak yang memiliki keterampilan bermain sentuh batu atau hitam dan hijau yang mana dalam pelaksanaannya cenderung dilakukan dengan berlari sambil mengejar lawan bermain dapat ditransfer kedalam keterampilan berlari sprint, namun masih perlu ditambahkan dengan teknik star dan melawati garis finis dalam pelaksanaan permainan tersebut sehingga memiliki keterampilan lari sprint yang utuh yaitu teknik star, berlari dan melewati garis finis.

Lari sprint bila kita amati dalam pelaksanaannya memiliki teknik-teknik khusu yang harus dilakukan pada saat mengikuti perlombaan agar dapat mencapai prestasi yang maksimal. Adapun teknik lari sprint yang harus dikuasai oleh pelari sprint adalah teknik start, teknik berlari, teknik melewati garis finis (Aip Syarifuddin, 1992:41). Teknik lari sprint tersebut harus dikuasai oleh pelari sprint karena teknik ini memiliki peran yang sangat penting untuk mencapai kecepatan maksimal.

Berlari merupakan suatu kegiatan yang dapat dilakukan oleh semua orang, karena berlari berarti melakukan perpindahan tempat dari suatu titik ke titik yang lain dengan ketentuan pada saat melakukan perpindahan terjadi posisi melayang atau ada saatnya salah satu anggota tubuh (telapak kaki) tidak menyentuh tanah. Menurut Lukman terdapat dua ciri berlari yaitu: (1) saat berlari ada kurun waktu yang pendek dimana tidak ada hubungan dengan permukaan, (2) berlari tidak ada kurun waktu dimana kedua kaki berhubungan dengan permukaan pada waktu yang sama, (Lukman O.T, 2003:121) .

Urutan langkah dalam setiap berlari akan mengalami fase menopang (support phase) dan fase melayang (flight phase). Langkah ini dapat dirinci menjadi fase topang depan dan fase dorong bagi kaki topang dan fase melayang yang dirinci menjadi fase ayun depan dan fase pemulihan, (Dididk Zafar Sidik, 2011:10). Pada saat melakukan fase topang depan akan terjadi perlambatan dorongan badan ke depan kemudian dipercepat kembali oleh fase dorong. Fase melayang kaki bebas mengayun mendahului badan sprinter dan 
diluruskan untuk persiapkan menyentuh tanah dan yang terakhir yaitu kaki topang dibengkokkan dan diayun kebadan sprinter, untuk lebih jelasnya dapat dilihat gambar berikut :

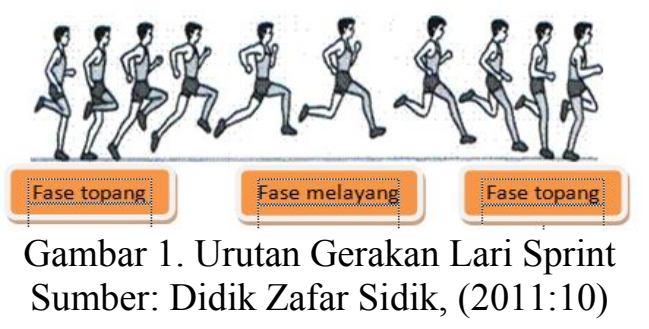

Kegaiatan di atas yaitu fase topang, fase melayang akan terjadi secara terus menerus selama seseorang melakukan kegiatan berlari. Unsur-unsur berlari dapat dibagi menjadi tiga kategori yaitu: (1) awalan, merupakan sikap saat melakukan start, yaitu: bersedia, siap dan ya, (2) berlari, sikap badan saatmelakukan berlari yaitu: sikap badan condong kedepan, ayunan tangan dan ayunan tungkai, (3) sikap memasuki garis finis, ayaitu posis tubuh saat memasuki garis finis. Hal di atas hampir sama dengan yang di ungkapkan Aip Syaripuddin bahwa terdapat tiga teknik yang harus dikuasai oleh pelari sprint yaitu (1) teknik start, (2) teknik berlari, (3) teknik melewati garis finis, (Aip Syarifiddin, 1992:64). Untuk lebih jelasnya mengenai teknik yang harus dikuasai oleh pelari sprint dapat dijelaskan sebagai berikut:

\section{a) Teknik start.}

Teknik start yang umum digunakan dalam perlombaan lari sprint adalah start jongkok (crouching start), dalam pelaksanaan start jongkok ada tiga macam, untuk penggunaannya tergantung atlitnya manah yang menjadi kesenangan mereka, adapun ketiga macam start jongkok tersebut adalah (1) start pendek (bunch satart) posisinya yaitu lutut sejajar dengan ujung kaki bagian depan, (2) start menengah (medium startt) posisinya yaitu lutut berada tengah-tengah antara ujung jari dengan tumit, (3) start panjang (longated startt) posisinya yaitu lutut sejajar dengan tumit. Jarak antara kaki dengan lutut baik untuk start pendek, menengah maupun panjang sama yaitu sekitar sebesar kepalan tanagan (tinju).

Dalam pelaksanaan start jongkok ada empat fase kegiatannya antara lain (1) posisi bersedia, (2) siaap, (3) gerakan dorong (4) lari akselerasi atau percepatan, (Didik Zafar Sidik, 2011:14). Pelaksanaan dari masing-masing fase adalah : fase posisi "bersedia" sprinter telah siap pada balok start dan langsung mengambil sikap awal, fase posisi "siaap" sprinter bergerak keposisi start secara optimal dengan mengangkat pinggulnya lebih tinggi dari pundak dengan kedua lutut sedikit dibengkokkan, meluruskan kedua lengannya yang bertumpu pada tanah dibelakang garis star, pandangan kedepan sekitar 1-1,5 meter kedepan, fase "gerakan dorong" sprinter menginggalkan balok startdan melakukan langkah pertama lari, posisi "lari akselerasi atau percepatan" sprinter menambah kecepatan lari dan melakukan transisi ke gerakan berlari, (Didik Zafar Sidik, 2011:14). Untuk lebih jelasnya dapat dilihat pada gambar berikut:

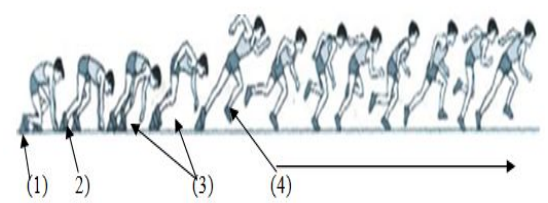

Gambar 2. Rangkaian Fase Gerakan Star Jongkok sampai berlari

Sumber: Didik Zafar Sidik, (2011:15)

Keterangan gambar 2 :

(1) Posisi "Bersedia" (2) Posisi "siaap" (3) Posis "Dorong" (4) Posisi Percepatan

Pelari sprint juga sangat diharapkan memiliki reflex yang tinggi karena sangat bermanfaat pada pelaksanaan start, selain itu harus memiliki power tungkai yang bermanfaat untuk gerakan dorong, dan kecepatan yang bermanfaat untuk percepatan lari.

\section{b) Teknik berlari}

Berlari merupakan kegiatan berpindah dari suatu tempat ketempat yang lainnya, dimana ada saatnya anggota tubuh (kaki) tidak menyentuh tanah atau berada pada posisi melayang. Hal ini sejalan dengan apa yang diungkapkan oleh Didik Zafar Sidik (2011:10) bahwa urutan gerakan berlari sprint terdiri dari fase topang, fase melayang. Untuk jelasnya posisi melayang pada saat berlari dapat dilihat pada gambar betikut:

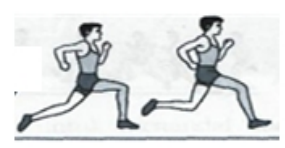

Gambar 3. Posisi Melayang pada saat Berlari Sumber: Didik Zafar Sidik, (2011:11).

\section{Keterangan Gambar: 3}

Gambar di atas terlihat bahwa posisi kaki pelari tidak menyentuh tanah berarti berada pada posisi melayang. 
Untuk teknik lari sprint yang harus dipahami dan dikuasai serta dapat dilakukan dengan benar, cepat, tepat, luwes dan lancar oleh para sprinter antara lain adalah: (1) lari dengan menggunakan ujung kaki, (2) lutut atau paha diangkat tinggi, (3) ayunan lengan atau tangan dari belakang ke depan, (4) badan condong ke depan, (Aip Syaripuddin, 1992:66).

Lari dengan ujung kaki yang dimaksud di atas adalah: pelari pada saat melangkahkan salah satu kakinya kedepan, kaki belakang yang paling terakhir menyentuh tanah adalah ujung kaki, demikian juga pada saat kaki depan mendarat di tanah yang paling dahulu menyentuh tanah adalah ujung kaki demikian seterusnya. Lari dengan lutut atau paha dianggkat tinggi yaitu: pelari saat mengayun kaki belakang kedepan secara bergantian lututnya atau pahanya hendaknya dianggkat tinggi dengan maksud memperlebar langkah sekaligus memperlambat ujung kaki menyentuh tanah. Lari dengan ayunan lengan atau tangan yaitu: bahwa pada saat kita berlari kedua lengan atau tangan diayun dari belakang ke depan secara bergantian dan dibengkokkan hingga membentuk sudut Sembilan puluh derajat $\left(90^{\circ}\right)$, gerakan ini dimaksudkan untuk memberikan keseimbangan dan daya dorong kedepan, telapak tangan terbuka. Lari dengan badan condong kedepan yaitu: bahwa pada saat berlari badan hendaknya condong kedepan secara wajar dan otot sekitar leher dan rahang tetap rileks dengan kepala dan punggung dalam posisi segaris. Hal ini dimaksudkan agar badan seolah olah jatuh kedepan sehingga kaki belakang cepat terangkat pindah kedepan begitulah seterusnya.

\section{c) Teknik melewati garis finis.}

Memasuki garis finish merupakan suatu hal yang sangat penting untuk mencapai sukses dalam mengikuti perlombaan lari sprint. Keterlambatan persekian detik memasuki garis finish sangatlah merugikan, apa lagi bila disebabkan hanya karena ketidak tahuan teknik melewati garis finis. Untuk menghindari agar tidak terjadi kerugian seperti yang dimaksud di atas, maka pelari lari jarak pendek sangat diharapkan memiliki pemahamam dan penguasaan terhadap prosedur teknik gerakan melewati garis finis dan konsep tentang cara melakukan gerakannya karena sangat besar kegunaannya terutama pada saat mengikuti perlombaan.

Tiga teknik yang biasa digunakan oleh para sprinter waktu melewati garis finis yaitu:
(1) dengan cara menjatuhkan dada kedepan, (2) dengan cara menjatuhkan salah satu bahunya kedepan, (3) dengan cara lari terus secepatcepatnya beberapa meter kedepan melewati garis finis, (Aip Syaripuddin, 1992:66). Adapun teknik melewati garis finis dengan menjatuhkan dada kedepan yaitu pada saat akan melewati garis finis, pelari membusungkan dadanya kedepan sambil berlari dengan cepat. Cara melewati garis finis dengan menjatuhkan salah satu bahu keden adalah pada saat akan melewati garis finis pelari menjatuhkan salah satu bahunya kedepan dengan cara memiringkan bahunya sambil berlari dengan cepat. Sementara cara melewati garis finis dengan lari terus secepatcepatnya sampai beberapa meter melewati garis finis adalah pelari pada saat akan melewati garis finis mereka berlari secepatcepatnya sampai melewati beberapa meter kedepan garis finis tersebut. Berikut contoh cara melewati garis finis.

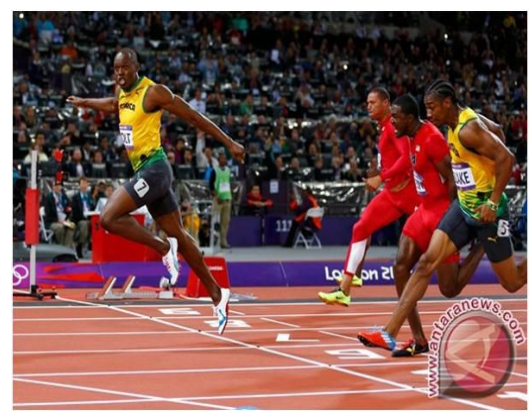

Gambar 4. Cara melewati garis finis dengan menjatuhkan dada kedepan.

Sumber: ANTARA News, Online; http://olimpiade.antaranews.com/berita/ 325796/bolt-pertahankan-gelar-100m-putra (Diakses 7 Maret 2015)

\section{Permainan Hitam Hijau}

Permainan hitam hijau merupakan permainan kecil tanpa alat. Dikatakan permainan kecil tanpa alat karena dalam pelaksanaannya tidak dibutuhkan peralatan khusus, seperti permainan lain yang menggunakan peralatan yang mana permainan tersebut tidak bias dimainkan apabila tidak ada alat dari permainan tersebut. Selain itu permainan ini belum meiliki wadah atau organisasi, (Aip Sarifuddin, 1992:135).

Dikatakan permainan hitam hijau karena anak-anak dibagi atas dua kelompok kemudian kelompok satu diberi nama hijau dan kelompok satunya lagi diberi nama hitam. Permainan ini dilakukan dengan saling 
mengejar antara kelompok hijau dan hitam, berikut lapangan permainan hitam hijau.

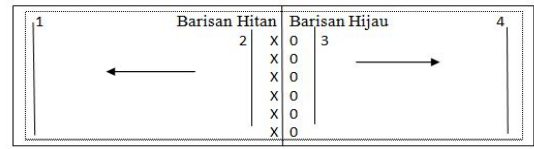

Gambar 5. Lapangan Permainan Hitam Hijau

Keterangan gambar:

$\mathrm{X} \quad=$ Anggota kelompok barisan hitam

0 = Anggota kelompok barisan hijau

$=-$ A Lah saat dikejar anggota

kelompok barisan hijau

* Arah Lari saat dikejar anggota

kelompok barisan hitam

No. 1 = Garis finis pada daerah Hitam

No. 2 = Garis star pada daerah Hitam

No. 3 = Garis star pada daerah Hijau

No. 4 = Daris finis pada daerah Hijau

Cara Pelaksanaan permainan Hitam Hijau yang digunakan dalam penelitian ini yaitu:

(a) Dilakukan pembagian anggota regu dengan jumlah yang sam.

(b) Memberi nama masing-masing regu (regu satu diberinama Hitam dan regu dua diberi nama Hijau).

(c) Dibariskan dengan membentuk dua saf dengan saling membelakangi.

(d) Memberi penjelasan apa yang harus dilakukan pada saat star dan saat melewati garis finis.

(e) Menganjurkan melakuan star jonggok sambil diarahkan oleh tenaga pembantu peneliti yang telah dilatih sebelumnya.

(f) Tenaga pembantu peneliti yang telah ditunjuk salah satu nama regu (Hitam atau Hijau), nama yang disebut harus berlari melewati garis finis dan dikejar oleh kelompok regu yang tidak disebut nama kelompoknya. (saat melewati garis finis anggota regu harus mempraktikkan cara melewati garis fini yang telah diarahkan oleh tenaga pembantu peneliti yang telah dilatih sebelumnya.

(g)Begitulah sterusnya dilakukan secara berulang-ulang.

\section{Permainan sentuh batu}

Pelaksanaan permainan ini dibutuhkan kebugaran jasmani, kecepatan berlari, kelincahan, kekuatan serta daya tahan jantung dan paru. Di daerah lain (masyarakat Wakatobi) permainan ini diberi nama Enggo-enggo, (Laode Taalami, 2008:75). Sementara menurut
A. Husna M, (2009:69) jenis permainan ini di beri nama permainan Pris-prisan.

Peralatan yang dibutuhkan dalam permainan ini adalah sesuai dengan namanya yaitu permainan sentuh batu. Jadi dibutuhkan duah buah batu berukuran sedang atau berukuran sekitar $10 \times 10 \mathrm{Cm}$, yang diletakkan secara berjahuan berjarak sekitar antara 10-15 meter (disesuaikan dengan luas area tempat bermain), jumlah pemain dalam satu regu antara $4-7$ orang (makin banyak jumlah pemain dalam satu regu makin bagus) namun harus disesuaikan dengan luas area tempat bermain.

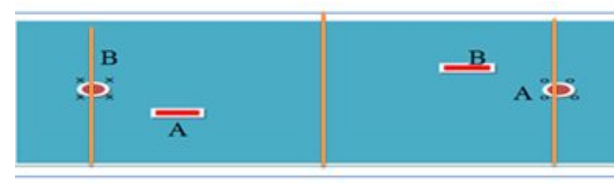

Gambar 6. Lapangan Permainan Sentuh Batu.

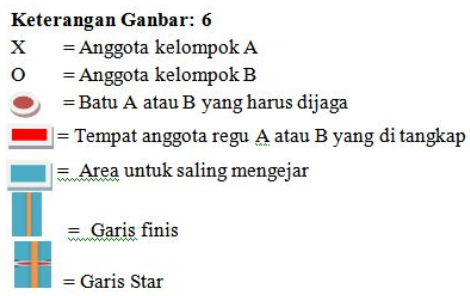

Cara pelaksanaan permainan sentuh batu yang digunakan pada penelitian ini yaitu :

(a) Pembagian anggota regu (diharapkan jumlahnya sama)

(b) Meletakkan kedua batu yang harus dijaga oleh masing-masing regu.

(c) Memberikan penjelasan tentang apa yang harus dilakukan saat memulai melakukan pengejaran dan saat melewati garis ditengah lapangan (garis finis).

(d) Dilakukan undian untuk menentukan regu mana yang akan terlebih dahulu salah satu teman satu regunya meninggalkan batunya untuk dikejar.

(e) Setelah diundi permainan dimulai (masingmasing regu berkerumun menginjak batunya).

(f) Setelah dimulai, regu yang telah ditetapkan salah satu temannya pertama kali meninggalkan batunya segera meninggalkan batunya namun harus mempraktikkan teknik star jongkok yang diarahkan oleh pembantu peneliti yang telah dilatih sebelumnya, dan saat melewati garis tengah lapangan harus mempraktikkan cara melewati garis finis yang diarhkan 
oleh tenaga pembantu peneliti yang telah dilatih sebelumnya.

(g) Kemudian lari menuju kearah mendekati batu lawan namun mereka harus menjaga agar tidak tertangkap oleh pihak lawan sambil memancing pihak lawan untuk mengejarnya.

(h) Pihak lawan harus mengejar, namun harus mempraktikkan teknik star jongkok yang diarahkan oleh pembantu penelitian yang telah dilatih sebelumnya, yang mengejar boleh 1 (satu) orang atau lebih (namun harus tetap ada yang menjaga batu) dan yang mengejar berusaha menangkap yang dikejar tersebut, pihak yang dikejar berlari secara bebas (sebatas lapangan yang telah ditepkan) namun boleh juga lari kembali ke batunya bergabung dengan kelompoknya yang menginjak batunya untuk menghindari tangkapan lawan.

(i) Saat temannya dalam satu regu yang dikejar, teman yang lain boleh membatu dengan cara mengejar lawan yang mengejar temannya tersebut dan berusaha menangkapnya. Karena ada yang membantu maka pihak yang mengejar tersebut berusaha agar tidak tertangkap oleh regu yang membantu temannya dan sebaiknya berlari kembali bergabung dengan temannya yang berkumpul menginjak batunya. Begitulah seterusnya saling mengejar.

(j) Apa bila dalam pelaksanaan saling mengejar ada yang tertangkap maka yang tertangkap disuruh berdiri sekitar 1,5 m dari batu lawan (makin banyak tertangkap makin bagus), yang tertangkap bisa bergabung dengan temannya lagi apa bila ada teman dalam satu regunya yang datang mengambil mereka, namun tidak mudah teman satu regunya mengambilnya karena dijaga oleh lawannya.

(k) Poin diperoleh apa bila salah satu anggota regu ada yang berhasil menyentuh batu dengan kaki yang dijaga oleh regu pemilik batu tersebut.

(1) Kemungkinan untuk mendapatkan poin apa bila salah satu regu banyak yang tertangkap sehingga batu yang dijaga oleh regu yang banyak ditangkap temannya bisa dikepung.dan ramai-ramai menyentuh batu dengan menggunakan kai, (setiap menyentuh batu poin yang diperoleh hanya 1 (satu) walaupun saat dikepung ramairamai menyentuh batu. (m) Pada saat ada salah satu anggota regu yang berhasil menyentuh batu maka permainan kembali seperti awal yaitu semua anggota regu berkumpul kembali di batunya masing-masing, dan memulai kembali permainan seperti awal.

(n) Pemenangnya adalah regu yang berhasil mengumpulkan poin lebih banyak.

(o) Ketentuan: pemain yang terlebih dahulu meninggalkan batunya itu yang berhak ditengkap.

(p) Begitulah seterusnya dialukan secara berulang-ulang.

\section{E. Hipotesis Penelitian}

Berdasarkan rumusan masalah yang ada,maka hipotesis penelitian adalah:

1. Terdapat kontribusi penerapan permainan hitam hijau terhadap keterampilan lari sprin murid SMP Negari 11 Kota Jambi.

2. Terdapat kontribusi penerapan permainan sentuh batu terhadap keterampilan lari sprin murid SMP Negari 11 Kota Jambi.

3. Terdapat perbedaan kontribusi antara permainan hitam hijau dengan sentuh batu terhadap keterampilan lari sprint Murid SMP Negeri 11 Kota Jambi.

\section{METODOLOGI PENELITIAN}

penelitian ini merupakan penelitian eksperimen, sebagaimana diungkapkan Sugiyono (2008: 107) bahwa dalam penelitian eksperimen ada perlakuan (treatment), Penelitian ini terdiri dari variabel terikat yaitu keterampilan lari sprint, variabel perlakuan yaitu permainan hitam hijau dan sentuh batu. Adapun rancangan perlakuan menggunakan Pretes Postes adalah seperti rancangan berikut:

\begin{tabular}{|ccc|}
\hline Pretes & Perlakuan Postes \\
\hline 01 & $\mathrm{X}(\mathrm{a})$ & 02 \\
\hline 01 & $\mathrm{X}(\mathrm{b})$ & 02 \\
\hline
\end{tabular}

Keterangan:

(a) Permainan Hitam Hujau

(b) Permainan Sentuh Batu

Sampel penelitian ini adalah siswa putra SMP Negri 11 kelas VII Kota Jambi yang berjumlah 62 orang. Teknik pengambilan sampel dilakukan dengan teknik cara undian untuk mendapatkan 62 sampel. Setelah didapatkan sampel maka dilakukan pengundian kembali untuk penempatan bentuk permainan yang diikuti. Berdasarkan kegiatan di atas, maka dapat dilakukan pengelompokkan sampel seperti berikut: 
Tabel 1. Pengelompokan Sampel Penelitian

\begin{tabular}{|c|c|c|c|}
\hline \multirow{2}{*}{ Variabel Terikat } & \multicolumn{2}{|c|}{ Permainan } & \multirow[b]{2}{*}{ Total } \\
\hline & \begin{tabular}{|c} 
Hitam Hijau \\
$\left(\mathrm{A}_{1}\right)$
\end{tabular} & $\begin{array}{c}\text { Sentuh Batu } \\
\left(\mathrm{A}_{2}\right)\end{array}$ & \\
\hline Ketera & 32 & 30 & 62 \\
\hline
\end{tabular}

Teknik pengumpulan data dalam penelitian ini adalah dengan melakukan tes keterampilan lari sprint sambil melakukan pengamatan dengan menggunakan lembar pengamatan untuk mendapatkan data keterampilan lari sprint. Cara pengumpulan data sebagai berikut:

1. Dilakukan tes pelaksanaan star jongkok, dengan menggunakan aba-aba bersedia, siap, ya. (dilakukan pengamatan terhadap tehnik star yang dilakukan)

2. Dilakukan tes lari sprint 40 meter (dilakukan pengamatan terhadap tehnik lari sprint yang dilakukan)

3. Dilakukan tes cara melewati garis finis (dilakukan pengamatan terhadap cara melewati garis finis yang dilakukan)

\section{HASIL DAN PEMBAHASAN}

\section{A. Deskripsi Data}

Hasil penelitian akan digambarkan sesuai dengan hipotesis yang diajukan sebelumnya. Berikut ini adalah deskripsi data dari hasil penelitian permainan Sentuh Batu (SB) dan permainan Hitam Hijau (HH).

Tabel 2 : Deskripsi data hasil penelitian Permainan ST dan HH
\begin{tabular}{|c|c|c|c|c|c|c|}
\hline Data & N & Rata-rata & s & $s^{2}$ & Skor Max & Skor Min \\
\hline Tes Awal SB & 30 & 18.50 & 5.30 & 28.12 & 30 & 9 \\
\hline Tes Akhir SB & 30 & 25.6 & 2.9 & 8.65 & 32 & 20 \\
\hline Tes AwalHH & 32 & 13.8 & 4.42 & 19.51 & 25 & 5 \\
\hline Tes Akhir HH & 32 & 24.8 & 4.69 & 21.96 & 33 & 11 \\
\hline
\end{tabular}

Berdasarkan analisis data (tabel 2) tes awal (pre test) kelompok permainan sentuh batu (SB) dengan jumlah sampel 30 diperoleh rata-rata (mean) 18.5, simpangan baku (SD) 5.3 , varians 28.12 , skor tertinggi 30 dan skor terendah 9. untuk lebih jelasnya dapat dilihat pada tabel 3 distribusi frekuensi di bawah ini:

\begin{tabular}{|c|c|c|c|c|c|}
\hline \multirow{2}{*}{ No } & \multirow{2}{*}{\multicolumn{3}{|c|}{ Rentangan Skor }} & \multicolumn{2}{|c|}{ frekuensi } \\
\hline & & & & Absolut & Relatif \\
\hline 1 & 8,5 & - & 13,5 & 6 & $20.00 \%$ \\
\hline 2 & 13,5 & - & 18,5 & 10 & $33.33 \%$ \\
\hline 3 & 18,5 & - & 23,5 & 9 & $30.00 \%$ \\
\hline 4 & 23,5 & - & 28,5 & 3 & $10.00 \%$ \\
\hline 5 & 28,5 & - & 33,5 & 2 & $6.67 \%$ \\
\hline \multicolumn{4}{|c|}{ Jumlah } & 30 & $100 \%$ \\
\hline
\end{tabular}

Dari tabel 3 di atas dapat dilihat bahwa pada hasil pre test 6 orang (20\%) berada pada rentangan skor $8,5-13,5$, ada 10 orang $(33.33 \%)$ berada pada rentangan skor 13,5 -
18,5 , ada 9 orang $(30 \%)$ berada pada rentangan skor 18,5 - 23,5 , ada 3 orang $(10 \%)$ berada pada rentangan skor $23,5-28,5$, ada 2 orang $(6.67 \%)$ berada pada rentangan skor $28,5-33,5$. Untuk lebih jelasnya dapat dilihat pada histogram berikut ini:

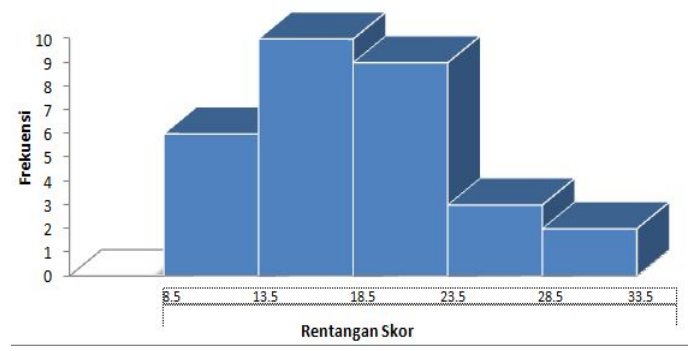

Gambar 7 : Histogram Tes Awal Kelompok Permainan SB

Berdasarkan analisis data (tabel 2) tes akhir (post test) kelompok permainan Sentuh Batu (SB) dengan jumlah sampel 30 diperoleh rata-rata (mean) 25.6, simpangan baku (SD) 2.9 , varians 8.65 , skor tertinggi 32 dan skor terendah 20. Untuk lebih jelasnya dapat dilihat pada tabel 4 distribusi frekuensi di bawah ini:

Tabel 4: Distribusi Frekuensi Tes Akhir Kelompok Permainan SB

\begin{tabular}{|c|c|c|c|c|c|}
\hline \multirow{2}{*}{ No } & \multirow{2}{*}{\multicolumn{3}{|c|}{ Rentangan Skor }} & \multicolumn{2}{|c|}{ Frekuensi } \\
\hline & & & & \multirow{2}{*}{$\frac{\text { Absolut }}{5}$} & \multirow{2}{*}{$\begin{array}{l}\text { Relatif } \\
16.67 \%\end{array}$} \\
\hline 1 & 19,5 & - & 22,5 & & \\
\hline 2 & 22,5 & - & 25,5 & 11 & $36.67 \%$ \\
\hline 3 & 25,5 & - & 28,5 & 8 & $26.67 \%$ \\
\hline 4 & 28,5 & - & 31,5 & 5 & $16.67 \%$ \\
\hline 5 & 31,5 & - & 34,5 & 1 & $3.33 \%$ \\
\hline \multicolumn{4}{|c|}{ Jumlah } & 30 & $100 \%$ \\
\hline
\end{tabular}

Dari tabel 4 di atas dapat dilihat bahwa pada hasil tes akhir 5 orang $(16.67 \%)$ berada pada rentangan skor 19,5 - 22,5, ada 11 orang $(36.67 \%)$ berada pada rentangan skor 22,5 25,5 , ada 8 orang $(26.67 \%)$ berada pada rentangan skor 25,5 - 28,5, ada 5 orang $(16.67 \%)$ berada pada rentangan skor 28,5 31,5 , ada 1 orang $(3.33 \%)$ berada pada rentangan skor 31,5 - 34,5. Untuk lebih jelasnya dapat dilihat pada histogram berikut ini:

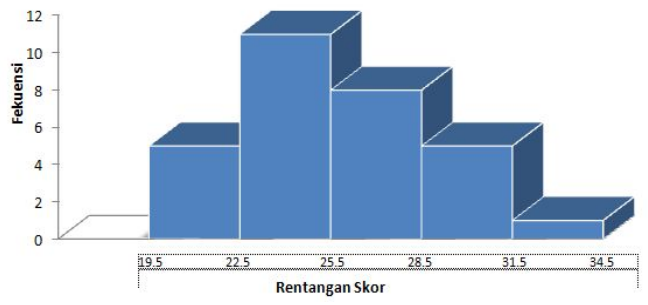

\section{Gambar 8 : Histogram Tes Akhir Kelompok SB}

Berdasarkan analisis data (tabel 2) tes awal (pre test) kelompok permainan Hitam Hijau (HH) jumlah sampel 32 diperoleh ratarata (mean) 13.8, simpangan baku (SD) 4.42, 
varians 19.51, skor tertinggi 25 dan skor terendah 5. untuk lebih jelasnya dapat dilihat pada tabel 5 distribusi frekuensi di bawah ini:

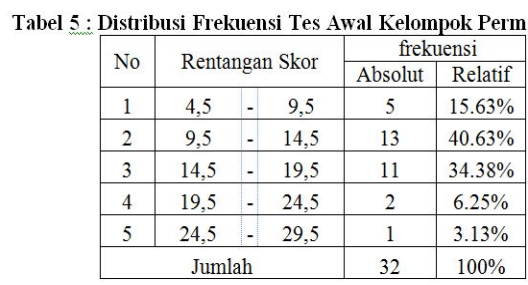

Dari tabel 5 di atas dapat dilihat bahwa pada hasil tes awal 5 orang $(15.63 \%)$ berada pada rentangan skor 4,5 - 9,5, ada 13 orang $(40.63 \%)$ berada pada rentangan skor 9,5 14,5 , ada 11 orang $(34.38 \%)$ berada pada rentangan skor 14,5 - 19,5, ada 2 orang $(6.25 \%)$ berada pada rentangan skor 19,5 - 24,5, ada 1 orang $(3.33 \%)$ berada pada rentangan skor $24,5-29,5$. Untuk lebih jelasnya dapat dilihat pada histogram berikut ini:

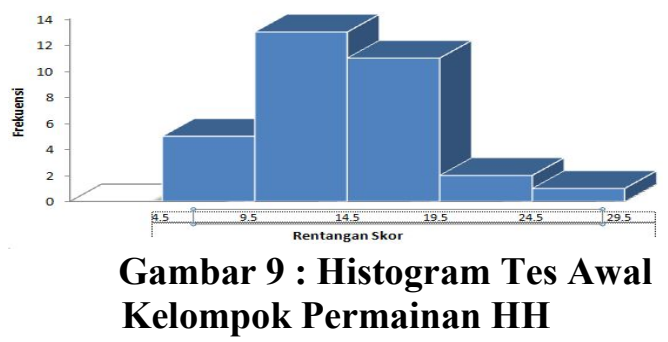

Berdasarkan analisis data (tabel 2) tes akhir (post test) kelompok permainan Hitam Hijau (HH) dengan jumlah sampel 32 diperoleh rata-rata (mean) 24.8, simpangan baku (SD) 4.69, varians 21.96, skor tertinggi 33 dan skor terendah 11. Untuk lebih jelasnya dapat dilihat pada tabel 6 distribusi frekuensi di bawah ini:

\begin{tabular}{|c|c|c|c|c|c|c|}
\hline \multirow{3}{*}{\multicolumn{2}{|c|}{\begin{tabular}{|c|} 
No \\
1 \\
\end{tabular}}} & \multirow{2}{*}{\multicolumn{3}{|c|}{ Rentangan Skor }} & \multicolumn{2}{|c|}{ frekuensi } \\
\hline & & & & & \multirow{2}{*}{$\frac{\text { Absolut }}{2}$} & \multirow{2}{*}{$\begin{array}{l}\text { Relatif } \\
6.25 \% \\
\end{array}$} \\
\hline & & 10,5 &. & 15,5 & & \\
\hline & 2 & 15,5 & - & 20,5 & 2 & $6.25 \%$ \\
\hline & 3 & 20,5 &. & 25,5 & 12 & $37.50 \%$ \\
\hline & 4 & 25,5 & - & 30,5 & 14 & $43.75 \%$ \\
\hline & 5 & 30,5 & - & 35,5 & 2 & $6.25 \%$ \\
\hline & & Jun & & & 32 & $100 \%$ \\
\hline
\end{tabular}

Dari tabel 6 di atas dapat dilihat bahwa pada hasil tes akhir 2 orang $(6.25 \%)$ berada pada rentangan skor $10,5-15,5$, ada 2 orang $(6.25 \%)$ berada pada rentangan skor 15,5 20,5 , ada 12 orang $(37.5 \%)$ berada pada rentangan skor 20,5 - 25,5, ada 14 orang $(43.75 \%)$ berada pada rentangan skor 25,5 30,5 , dan ada 2 orang $(6.25 \%)$ berada pada rentangan skor 30,5 - 35,5. Untuk lebih jelasnya dapat dilihat pada histogram berikut ini:

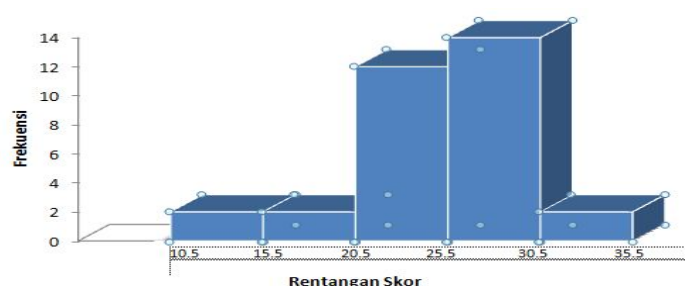

Gambar 10 : Histogram Tes Akhir Kelompok HH

Pengujian Hipotesis penelitian ini diuji dengan menggunakan analisis Uji t. Sebelum dilakukan analisis uji $t$ terlebih dahulu dilakukan uji normalitas dan uji homogenitas. Taraf signifikansi $\alpha>0,05$. Dari hasil pengolahan dinyatakan Normal dan homogen.

Instumen Non Test (lembar observasi) Keterampilan Lari Sprint sebelum digunakan sebagai instrumen pengumpulan data terlebih dahulu dilakukan uji coba mengetahui apakah lembar observasi tersebut valid dan reliabel atau tidak. Berdasarkan hasil analisis factor, dengan mengkorelasikan antara skor item instrument dengan rumus Pearson Product Moment, dengan $\alpha=0.05$ dan derajat kebebasan $(\mathrm{dk}=\mathrm{n}-2)$. Kaidah keputusan: Berdasarkan hasil pengujian instrumen keteramplan lari sprint dinyatakan valid dan reliabel dan dapat digunakan untuk pengumpulan data keterampilan lari sprint terhadap sampel penelitian.

\section{B. Pengujian Hipotesis}

Setelah uji persyaratan analisis dilakukan dan ternyata semua data tiap variabel penelitian memenuhi persyaratan untuk dilakukan pengujian statistik lebih lanjut, maka selanjutnya dilaksanakan pengujian hipotesis, pada penelitian ini ada tiga hipotesis penelitian, yaitu: (1) terdapat kontribusi permainan hitam hijau $(\mathrm{HH})$ terhadap keterampilan lari sprint murid SMP 11 Kota Jambi, (2) terdapat kontribusi permainan entuh batu (SB) terhadap keterampilan lari sprint murid SMP 11 Kota Jambi dan (3) terdapat perbedaan kontribusi permainan hitam hijau $(\mathrm{HH})$ dengan sentuh batu (SB) terhadap keterampilan lari sprint murid SMP 11 Kota Jambi. Berikut ini disajikan hasil pengujian terhadap hipotesis penelitian yang telah diajukan di atas.

1.

Terda

pat Kontribusi Permainan Hitam Hijau (HH) Terhadap Keterampilan Lari Sprint

Berdasarkan hasil Uji statistik menggunakan t-test untuk mengetahui pengaruh rerata hitung dalam satu kelompok 
yang sama pada taraf signifikan 0,05 . Hasil tes akhir (post test) keterampilan lari sprint pada kelompok permainan hitam hijau dengan jumlah sampel 32 orang, dapat diketahui hasil pengujian hipotesis yang di sajikan dalam tabel 10 berikut ini:

\begin{tabular}{|c|c|c|c|c|c|c|c|}
\hline \multicolumn{8}{|c|}{ Tabel ": Rangkiunmant Hasil Pengujujan Hipotesis 1} \\
\hline Kelompok & Neall & SD & $t_{\text {hitung }}$ & A & $\mathrm{t}_{\text {tabe }}$ & Hisil Lji & Keteringall \\
\hline Pretest & 13,81 & 4,42 & \multirow{2}{*}{9,35} & \multirow{2}{*}{0} & \multirow{2}{*}{1,69} & \multirow{2}{*}{ Signifikan } & \multirow{2}{*}{$\begin{array}{l}\text { Ho ditolak } \\
\text { Ha diteriman }\end{array}$} \\
\hline Posstest & 24,81 & 4,69 & & & & & \\
\hline
\end{tabular}

Berdasarkan tabel 7 di atas dapat diketahui bahwa $t_{\text {hitung }}(9,35)>t_{\text {tabel }}(1,69)$. Hal ini berarti bahwa hipotesis penelitian dapat diterima. Dengan demikian dapat disimpulkan bahwa permainan hitam hujau memberikan kontribusi yang signifikan terhadap keterampilan lari sprint. Hal ini dapat terjadi karena dalam pelaksanaan permainan hitam hijau terjadi saling kejar mengejar dengan menggunakan kemampuan penuh, (berhenti berlari setelah melawati garis akhir lapangan atau finis) dengan ini terjadi pelaksanaan berlari dengan sungguh sungguh, saat itu juga anggota permainan mempraktikkan gerakan berlari seperti mengangkat paha tinggi, mengayunkan lengan serta melewati garis finis, dengan inlah sehingga terbentuk keterampilan lari sprint pada anggota permainan tersebut, dengan demikian terdapat kontribusi permainan hitam hijau terhadap keterampilan lari sprint.

\section{Terdapat Kontribusi Permainan Sentuh Batu (SB) Terhadap Keterampilan Lari Sprint}

Berdasarkan hasil Uji statistik menggunakan t-test untuk mengetahui pengaruh rerata hitung dalam satu kelompok yang sama pada taraf signifikan 0,05 . Hasil tes akhir (post test) keterampilan lari sprint pada kelompok permainan sentuh batu dengan jumlah sampel 30 orang. Adapun Hasil pengujian Hipotesis di sajikan dalam tabel berikut ini:

\begin{tabular}{|c|c|c|c|c|c|c|c|}
\hline Kelompok & Mean & SD & $t_{\text {hitung }}$ & A & $t_{\text {tabel }}$ & Hasil Uji & Keterangan \\
\hline Pretest & 18,5 & 5,3 & \multirow[b]{2}{*}{14} & \multirow{2}{*}{0,05} & \multirow{2}{*}{1,69} & \multirow{2}{*}{$\underset{\text { Signifika }}{\text { Sign }}$} & \multirow{2}{*}{$\begin{array}{l}\text { Ho ditolak } \\
\text { Ha diterima }\end{array}$} \\
\hline Post test & 25,63 & 2,94 & & & & & \\
\hline
\end{tabular}

Berdasarkan tabel 8 di dapat dilihat bahwa $t_{\text {hitung }}(6,44)>t_{\text {tabel }}(1,69)$. Hal ini berarti bahwa hipotesis penelitian dapat diterima. Dengan demikian dapat disimpulkan bahwa permainan sentuh batu memberikan kontribusi yang signifikan terhadap keterampilan lari sprint. Hal ini dapat terjadi karena pada pelaksanaan permainan sentuh batu peserta permainan saling kejar mengejar sambil mempraktikkan teknik berlari berdasarkan aturan permainan yang telah disampaikan sebelumnya, seperti harus mempraktikkan cara melewati garis finis saat melewati garis di tengah lapang, saat mengejar atau dikejar harus mempraktikkan cara berlari dengan mengangkat paha tinggi, badan dicondongkan kedepan, lengan diayunkan dan setiap memulai permainan hendaknya mempraktikkan teknik star jonggkok, dengan inilah sehingga terbentuk keterampilan berlari pada anggota permainan tersebut, dengan demikian terdapat kontribusi permainan sentuh batu terhadap keterampilan lari sprint.

\section{Terdapat Perbedaan Kontribusi Permainan Hitam Hijau (HH) Dengan Sentuh Batu (SB) Terhadap Keterampilan Lari Sprint}

Berdasarkan hasil Uji statistik menggunakan t-test untuk mengetahui pengaruh rerata hitung dalam dua kelompok yang berbeda pada taraf signifikan 0,05 . Hasil tes akhir (post test) keterampilan lari sprint pada kelompok hitam hijau dengan jumlah sampel 32 orang sedangkan kelompok permainan sentuh batu dengan jumlah sampel 30 orang. Adapun Hasil pengujian Hipotesis di sajikan dalam tabel ? berikut ini:

Tabel 9 : Rangkuman Hasil Pengujian Hipotesis 3

\begin{tabular}{|c|c|c|c|c|c|}
\hline Permainan & $t_{\text {hitung }}$ & A & $\mathrm{t}_{\text {tabel }}$ & Hasil Uji & Keterangan \\
\hline Hitam Hijaı & \multirow{2}{*}{4,54} & \multirow{2}{*}{0,05} & \multirow{2}{*}{2,24} & \multirow{2}{*}{ Signifikan } & \multirow{2}{*}{$\begin{array}{l}\text { Ho ditolak } \\
\text { Ha diterima }\end{array}$} \\
\hline Sentuh Batı & & & & & \\
\hline
\end{tabular}

Berdasarkan tabel 9 di atas dapat dilihat bahwa $t_{\text {hitung }}(4,54)>t_{\text {tabel }}(2,24)$. Hal ini berarti bahwa hipotesis penelitian dapat diterima. Dengan demikian dapat disimpulkan bahwa terdapat perbedaan kontribusi permainan hitam hijau dengan permainan sentuh batu secara signifikan terhadap keterampilan lari sprint, dalam hal ini yang lebih baik adalah permainan hitamhijau $(\mathrm{HH})$, hal ini terjadi karena pada pelaksanaan permainan hitam hijau $(\mathrm{HH})$ tidak ada kesempatan berhenti berlari sebelum sampai pada garis finis, pelaksanaan berlari dilakukan dengan lurus, artinya mereka mempraktikkan berlari lebih lama dan kecepatan berlarinya tetap cepat, sehingga penerapan keterampilan lari sprint lebih terarah dan lebih mudah serta lebih berkesinambungan. sementara pada permainan sentuh batu (SB) ada saatnya berhenti berlari di tengah lapangan saat menunggu lawan untuk mengejar mereka 
atau saat mendekati batu lawan mereka harus mengurangi kecepatan berlarinya (pelan) bahkan bias berhenti karena mereka takut tertangkap lawan, permainan sentuh batu kegiatan berlari bisa dilakukan sambil membelok-belok untuk menghindari tangkapan lawan sehingga penerapan keterampilan lari sprint terputus-putus sehingga tidak terjadi secara berkesinambungan.

\section{KESIMPULAN DAN SARAN}

Berdasarkan hasil penelitian, pengajuan hipotesis dan analisis data serta pembahasan yang telah dilakukan, maka dapat disimpulkan sebagai berikut :

1. Permainan hitam hijau berkontribusi terhadap keterampilan lari sprin murid SMP Negari 11 Kota Jambi.

2. Permainan sentuh batu berkontribusi terhadap keterampilan lari sprin murid SMP Negari 11 Kota Jambi.

3. Permainan hitam hijau dan sentuh batu memiliki perbedaan kontribusi terhadap keterampilan lari sprint Murid SMP Negeri 11 Kota Jambi. Permainan hitam hijau memiliki kontribusi lebih baik daripada permainan sentuh batu.

\section{DAFTAR PUSTAKA}

A. Husna M, 2009. 100+Permainan Tradisional Indonesia, untuk kreativitas, Ketangkasan, dan Keakraban, Andi Offset. Yogyakarta.

Aip Syarifuddin, 1992. Atletik, (Departemen Pendidikan dan Kebudayaan Direktorat Jenderal Pendidikan Tinggi Proyek Pembinaan Tenaga Kependidikan. Jakarta.

ANTARA News, Online; http://olimpiade.antaranews.com/berita/ 325796/bolt-pertahankan-gelar-100mputra Diakses 7 Maret 2015.

Coker, A Cherly, 2004. Motor Learning and control Practitioner. New Mexico: McGrawHill.

Dikdik Zafar Sidik, 2011. Mengajar dan Melatih Atletik PT. Remaja Rosdakarya offset. Bandung.

Dini Rosdiani, 2012. Model Pembelajaran Langsung dalam Pendidikan Jasmani dan Kesehatan, ALPABETA. Bandung. http:// keterampilansikaladi.blogspot. com/2013/07/defenisi-atau-pengertianketerampilan. html diakses tanggal 4 juni 2015. http://repository.upi.edu/operator/upload/s jkr_0605488 chapter2.pdf (Diakses 3 Juni 2015).

Ismail, Andang. 2006. Education Games. Pilar Media. Yogyakarta

H.Y.S. Santosa Giriwijoyo dan Didik Zafar Sidik, 2012, Ilmu Kesehatan Olahraga, P.T. Remaja Rosdakarya Offset. Bandung.

Laode Taalami, 2008. Mengenal Budaya Wakatobi, Granada. Jakarta.

Lukman O.T, 2003. Biomekanika Penerapan Hukum dan Prinsip Mekanika UNESA. Surabaya.

Ricard A Schmidt, 1988. Motor Learning And Control : a Behavior Emphasis, (Champaigh llionis: Human Kinetics Publshers, Inc.

Robert N Singer, 1992. The Learning Of Motor Skill. New York: Mc millan Publshing co.Inc.

Rusli Lutan, 1988. Belajar Keterampilan Motorik Pengantar Teori dan Metode. Depdikbud. Ditjen Dikti. Proyek Pengembangan Lembaga Pendidikan Tenaga Kependidikan. Jakarta.

Sugiyono, 2008. Metode Penelitian Pendidikan, Pendekatan Kuantitatif, Kualitatif, dan $R \& D$ CV. Alfabeta. Bandung.

Undang-undang Republik Indonesia Nomor 20 tahun 2003, tentang Sistem Pendidikan Nasional, Bab II, Pasal 3. Jakarta.

Wardani, Dani. 2008. Bermain Sambil Belajar. Edukasi. Bandung.

Wollacot and Shumway, 2001. Motor Control: Theori and Practical Aplications. Philadelphia: Lippincott.

W.S, Winkell. 2004 Psikologi Pengajaran. PT. Gramedia. Yogyakarta. 